\title{
Correction to: Korea hypertension fact sheet 2020: analysis of nationwide population-based data
}

Hyeon Chang Kim ${ }^{1,2^{*}}$, So Mi Jemma Cho ${ }^{3}$, Hokyou Lee ${ }^{1,2}$, Hyeok-Hee Lee ${ }^{1,2}$, Jongmin Baek ${ }^{1}$, Ji Eun Heo ${ }^{3}$ and for the Korean Society of Hypertension (KSH) - Hypertension Epidemiology Research Working Group

\section{Correction to: Clin Hypertens 27, 8 (2021) \\ https://doi.org/10.1186/s40885-021-00166-2}

In the original publication of this article [1] there were 2 incorrect mentions of KNHANES (Korea National Health and Nutrition Examination Survey). These were as followed:

\section{Results}

- Magnitude of hypertension: based on the KNHNAES

- Hypertension in young adults: based on the KNHAES and NHI-big data

These abbreviations have been corrected in the original article.

\section{Author details}

${ }^{1}$ Department of Preventive Medicine, Yonsei University College of Medicine, Seoul 03722, South Korea. ${ }^{2}$ Department of Internal Medicine, Yonsei University College of Medicine, Seoul 03722, South Korea. ${ }^{3}$ Department of Public Health, Yonsei University Graduate School, Seoul 03722, South Korea.

Published online: 29 March 2021

\section{Reference}

1. Kim HC, Cho SMJ, Lee H, et al. Korea hypertension fact sheet 2020: analysis of nationwide population-based data. Clin Hypertens. 2021;27:8 https://doi. org/10.1186/s40885-021-00166-2.

The original article can be found online at https://doi.org/10.1186/s40885021-00166-2.

* Correspondence: eshela.nir@mail.huji.ac.il

'Department of Preventive Medicine, Yonsei University College of Medicine, Seoul 03722, South Korea

2Department of Internal Medicine, Yonsei University College of Medicine, Seoul 03722, South Korea

Full list of author information is available at the end of the article

(c) The Author(s). 2021 Open Access This article is licensed under a Creative Commons Attribution 4.0 International License, which permits use, sharing, adaptation, distribution and reproduction in any medium or format, as long as you give appropriate credit to the original author(s) and the source, provide a link to the Creative Commons licence, and indicate if changes were made. The images or other third party material in this article are included in the article's Creative Commons licence, unless indicated otherwise in a credit line to the material. If material is not included in the article's Creative Commons licence and your intended use is not permitted by statutory regulation or exceeds the permitted use, you will need to obtain permission directly from the copyright holder. To view a copy of this licence, visit http://creativecommons.org/licenses/by/4.0/. The Creative Commons Public Domain Dedication waiver (http://creativecommons.org/publicdomain/zero/1.0/) applies to the data made available in this article, unless otherwise stated in a credit line to the data. 